\title{
IMPLEMENTASI MODEL PEMBELAJARAN ARCS (ATTENTION, RELEVANCE, CONFIDENCE, AND SATISFACTION) PADA MATA PELAJARAN PEKERJAAN DASAR TEKNIK OTOMOTIF (PDTO) UNTUK MENINGKATKAN KEAKTIFAN DAN HASIL BELAJAR SISWA KELAS X TKR A TEKNIK KENDARAAN RINGAN DI SMK NASIONAL BERBAH TAHUN AJARAN 2019/2020
}

\author{
Muhammad Solikhin* \\ Fakultas Teknik, Universitas Negeri Yogyakarta \\ *Corresponding Author: muhammadsolikhin281@gmail.com
}

\begin{abstract}
This reserach aims to improve the activeness and learning outcomes of Class X TKR A students in the SMK Nasional Berbah on the subject of Automotive Engineering Basic Work through the implementation of the ARCS learning model. This type of research is a classroom action research, using Kemmis and Mc. Taggart. The subjects of the study were students of class X Light Vehicle Engineering (TKR) A at the National Vocational School of Berbah in the academic year 2019/2020. Data was collected through observation sheets to determine student activity with numerical rating scale with indicator aspects in the form of students 'courage to ask questions, students' courage to answer questions / express opinions, students 'interactions with teachers and groups, students' attention during the learning process, and evaluation test to find out the level of student learning outcomes. The ARCS learning model is said to be successful in increasing activity and learning outcomes if the percentage of activeness reaches $65 \%$ and as many as $75 \%$ of students have completed KKM, namely learning outcomes of at least 75. The results of the study show that: 1) the implementation of the ARCS learning model in the learning process increases the activeness of class X TKR students A at SMK Nasional Berbah. This is indicated by the active learning of students in the first cycle $55.60 \%$ increased in the second cycle of $73.71 \%$. 2) The implementation of the ARCS learning model can improve student learning outcomes. This is indicated by the average value in the first cycle of 57.5 increased in the second cycle with an average class of 75 . with a final percentage of completeness of $82 \%$ and the percentage of activity reached $73.71 \%$ in the second cycle. Thus has reached the specified indicators of success.
\end{abstract}

Keywords: ARCS Learning Model, Learning Activity, Learning Outcomes.

\section{Abstrak}

Penelitian ini bertujuan untuk meningkatkan keaktifan dan hasil belajar siswa kelas X TKR A di SMK Nasional Berbah pada mata pelajaran Pekerjaan Dasar Teknik Otomotif melalui implementasi model pembelajaran ARCS. Jenis penelitian ini adalah penelitian tindakan kelas, dengan menggunakan model Kemmis dan Mc. Taggart. Subjek penelitian adalah siswa kelas X TKR A di SMK Nasional Berbah tahun ajaran 2019/2020. Pengambilan data dilakukan melalui lembar observasi untuk mengetahui keaktifan siswa dengan jenis numerical rating scale dengan aspek indikator berupa keberanian peserta didik bertanya, keberanian peserta didik untuk menjawab pertanyaan/mengungkapkan pendapat, interaksi peserta didik dengan guru dan kelompok, perhatian peserta didik selama proses pembelajaran, serta tes evaluasi untuk mengetahui tingkat hasil belajar siswa. Model pembelajaran ARCS dikatakan berhasil meningkatkan keaktifan dan hasil belajar apabila persentase keaktifan mencapai $65 \%$ dan sebanyak $75 \%$ siswa telah tuntas KKM yaitu hasil belajar minimal 75. Hasil penelitian menunjukkan bahwa: 1) implementasi model pembelajaran ARCS pada 


\section{Muhammad Solikhin}

proses pembelajaran meningkatkan keaktifan siswa kelas X TKR A di SMK Nasional Berbah. Hal ini ditunjukkan dengan keaktifan belajar siswa pada siklus I 55,60 \% meningkat pada siklus II sebesar 73,71 $\%$. 2) Implementasi model pembelajaran ARCS mampu meningkatkan hasil belajar siswa. Hal ini ditunjukkan dengan nilai rata-rata pada siklus I sebesar 57,5 meingkat pada siklus II dengan rata-rata kelasnya sebesar 75 . dengan persentase ketuntasan akhir sebesar $82 \%$ dan persentase keaktifan mencapai 73,71 \% di siklus II. Dengan demikian telah mencapai indikator keberhasilan yang ditentukan.

\section{Kata kunci: Reciprocal Teaching, Hasil Belajar, Teknologi Dasar Otomotif.}

\section{PENDAHULUAN}

Pendidikan merupakan suatu manifesti dalam suatu peradaban, dengan pendidikan yang unggul dapat mencetak sumber daya manusia yang berkualitas. Sumber daya manusia mempunyai peranan yang sangat penting dalam kemajuan suatu bangsa, sebab bangsa yang maju, unggul, dan berorientasi pada pembangunan dalam aspek segala bidang tentunya tidak terlepas dari pendidikan. Pendidikan merupakan suatu wadah kegiatan yang dapat dipandang sebagai pencetak sumber daya manusia (SDM) yang bermutu tinggi. Selain itu pendidikan berfungsi sebagai upaya dalam mengembangkan kemampuan yang dimiliki oleh siswa secara potensial dan aktual. Pengembangan kemampuan dapat dilakukan melalui proses pembelajaran baik secara formal maupun informal. Proses pembelajaran ini memerlukan keaktifan baik dari pendidik maupun siswa. Keberhasilan dalam proses pembelajaran dipengaruhi oleh beberapa hal, antara lain alat pendukung berupa fasilitas pembelajaran, materi pembelajaran, media pembelajaran, metode atau strategi pembelajaran dan lain-lain. (Nana Syaodih Sukmadinata, 2012: 57).

Sekolah Menengah Kejuruan (SMK), merupakan pendidikan dengan kompetensi keahlian dari bidang-bidang kejuruan, sebagaimana menurut penjelasan Undang-Undang Sistem Pendidikan Nasional (UU Sisdiknas) Nomor 20 Tahun 2003 Pasal 15 Depdiknas (2006:8), merupakan pendidikan menengah yang mempersiapkan peserta terutama untuk bekerja dalam bidang keahlian tertentu. Dengan harapan dapat menciptakan tenaga kerja yang memiliki pengetahuan, keterampilan, dan sikap kerja yang sesuai dengan kebutuhan industri. Lulusan SMK ini dipersiapkan sebagai sumber daya manusia yang siap pakai selain itu juga dapat menerapkan ilmu yang telah mereka dapat sewaktu di sekolah untuk mengatasi permasalahan-permasalahan di lingkungan masyarakat.

Jenjang pendidikan di SMK dalam proses pembelajarannya siswa dibimbing oleh guru yang berperan sebagai fasilitator untuk membantu mencapai tujuan belajar. Berbagai cara yang dapat digunakan oleh guru untuk menunjang proses pembelajaran salah satunya adalah dengan menggunakan strategi pembelajaran yang efektif, penggunaan media pendukung pembelajaran seperti buku teks, buku sekolah elektronik, gambar, audio, film animasi dan lain-lain. Penggunaan perangkat pembelajaran tersebut akan efektif apabila disesuaikan dengan metode 
yang sesuai dengan karakter siswa yang ada di dalam sekolah, jenis mata pelajaran yang disampaikan, kondisi lingkungan dan sarana yang menunjang.

Keberhasilan dalam pelaksanaan proses pembelajaran ini merupakan tugas dari seorang pendidik atau guru, sebab guru merupakan perancang awal strategi pembelajaran di dalam kelas agar tujuan pembelajaran dapat tercapai. Salah satu peran guru adalah sebagai demonstrator yakni guru harus dapat menunjukkan bagaimana caranya agar setiap materi pembelajaran bisa lebih dipahami dan dihayati oleh setiap siswa (Sofyan, 2015). Belajar pada hakikatnya adalah suatu proses interaksi terhadap semua situasi yang ada di sekitar individu. Belajar dapat dipandang sebagai proses yang diarahkan untuk mencapai tujuan pembelajaran. Pendidikan yang demokratis harus mampu menciptakan interaksi antara guru dan siswa dalam proses pembelajaran. Tujuannya adalah untuk menggali kemampuan siswa agar berperan secara aktif, meningkatkan kemampuan intelektual, sikap dan minatnya (Sofyan, et al., 2019)

SMK Nasional Berbah dengan visinya yaitu menjadi sekolah yang berkualitas dan berwawasan lingkungan. Sejalan dengan visi tersebut maka dalam upaya mewujudkannya didukung oleh beberapa cara yaitu melaksanakan pendidikan dan pelatihan yang berwawasan pada kebutuhan dunia kerja. Dalam mewujudkan sekolahan yang berkualitas tentunya sangat didukung dengan proses kegiatan pembelajaran sehari-hari yang meliputi penerapan strategi pembelajaran, model pembelajaran yang digunakan sehingga dalam hal itu siswa dapat memahami dengan mudah apa yang disampaikan oleh guru dalam kegiatan belajar mengajar..

Dalam mewujudkan branding sekolah berbasis industri melalui layanan pendidikan Link and Match bekerja sama dengan bidang industri. Dengan bekerja sama dengan industri maka laanan pendidikan kejuruan diberikan dengan relevansi mengacu pada industri tersebut. Kerja sama yang sudah dilakukan SMK Nasional Berbah jurusan Teknik Kendaraan Ringan (TKR) yaitu dengan PT. Daihatsu. Tentu dalam proses pembelajaran, materi pembelajara produktifnya disesuaikan dengan industri terkait. Salah satunya yaitu pada mata pelajaran Pekerjaan Dasar Teknik Otomotif (PDTO). Mata pelajaran Pekerjaan Dasar Teknik Otomotif adalah salah satu pelajaran produktif yang ditempuh di kelas $\mathrm{X}$, mata pelajaran yang bersifat wajib lulus dan ditempuh oleh siswa dengan pokok pembelajarannya di semester genap ini meliputi penggunaan alat-alat ukur mekanik dan fungsinya.

Hasil pengamatan dan wawancara pada guru teknik kendaraan ringan ketika pembelajaran Pekerjaan Dasar Teknik Otomotif (PDTO) yang dilakukan di SMK Nasional Berbah pada kelas X Teknik Kendaraan Ringan (TKR) pada tanggal 03 September 2019 bahwa guru masih menggunakan model pembelajaran konvensional dimana guru menerangkan suatu konsep, lalu siswa mengamati contoh soal dan dilanjutkan dengan latihan, kemudian siswa menjawab soal sesuai urutan penyelesaian yang diterangkan oleh guru. Selain itu dalam 
76 Muhammad Solikhin

kegiatan pembelajarannya walaupun sudah didukung dengan media LCD Proyektor akan tetapi pembelajaran yang siswa rasakan menjadi kurang memperhatikan materi yang disampaikan oleh guru sehingga ketika proses guru menerangkan pembelajaran siswa dikelas kurang aktif dalam pembelajaran dan menyebabkan siswa mudah kehilangan konsentrasi, bercanda sendiri bahkan ada yang tertidur. Hal ini menjadi salah satu penyebab rendahnya hasil belajar yang dicapai oleh siswa kelas X TKR A siswa menjadi kurang maksimal. Dari hasil Penilaian Tengah Semester (PTS) tahun ajaran 2019/2020 pada mata pelajaran PDTO di kelas X TKR A, dari 39 siswa, sebanyak 38 siswa belum mampu mencapai nilai kriteria ketuntasan minimal (KKM) 75.00 .

Kondisi ideal pembelajaran Pekerjaan Dasar Teknik Otomotif (PDTO) di SMK Nasional Berbah di kelas X TKR A dalam kegiatan pembelajarannya siswa cenderung bersifat pasif dalam pembelajaran, hal ini diakibatkan beberapa faktor satu diantaranya motivasi dalam kegiatan pembelajaran. Berdasarkan dari hasil pengamatan sehari-hari dalam kegiatan pembelajaran yang berlangsung sering terdapat siswa yang tidak hadir dalam kegiatan pembelajaran, tertidur ketika pembelajaran berlangsung dan bersifat pasif saat pembelajaran. Hal itu akan berdampak pada hasil belajar siswa.

Dari beberapa permasalahan yang dipaparkan diatas, permasalahan yang diangkat dalam penelitian ini adalah kurangnya minat dan motivasi siswa terhadap materi pelajaran akibat rendahnya keaktifan siswa dalam proses belajar.Hal ini apabila terus dibiarkan maka akan berdampak pada prestasi belajar dan hasil belajar siswa. Maka dari itu, penelitia ini difokuskan pada implementasi model pembelajaran yang mampu meningkatkan partisipasi aktif siswa dalam kegiatan belajar, yaitu Implementasi Model Pembelajaran ARCS (Attention, Relevance Confidence, and Satisfaction) Pada Mata Pelajaran Pekerjaan Dasar Teknik Otomotif (PDTO) Untuk Meningkatkan Keaktifan Dan Hasil Belajar Siswa Kelas X TKR A Teknik Kendaraan Ringan Di SMK Nasional Berbah Tahun Ajaran 2019/2020. Kemudian masalah dalam penelitian ini dapat dirumuskan sebagai berikut. (1) apakah implementasi model pembelajaran ARCS (Attention, Relevance Confidence, and Satisfaction) dapat meningkatkan keaktifan siswa kelas X TKR A pada mata pelajaran Pekerjaan Dasar Teknik Otomotif (PDTO) di SMK Nasional Berbah, (2) apakah implementasi model pembelajaran ARCS (Attention, Relevance Confidence, and Satisfaction) dapat meningkatkan hasil belajar siswa kelas X TKR A pada mata pelajaran Pekerjaan Dasar Teknik Otomotif (PDTO) di SMK Nasional Berbah.

Tujuan penelitian ini adalah untuk meningkatkan keaktifan dan hasil belajar siswa di kelas X TKR A pada mata pelajaran Pekerjaan Dasar Teknik Otomotif (PDTO). Pada penelitian ini dilakukan inovasi dari guru yang sebelumnya menggunakan metode ceramah menjadi implementasi model pembelajaran ARCS. Model pembelajaran ARCS merupakan model 
pembelajaran yang dapat mempengaruhi motivasi berprestasi dan hasil belajar, model ini dikembangkan oleh Keller dan Kopp (1987) yang berdasarkan pada teori nilai harapan (expectancy value theory) yang mengandung dua komponen yaitu nilai (value) dari tujuan yang akan dicapai dan harapan (expectancy) agar berhasil mencapai tujuan yang diharapkan. Model ARCS juga terkenal dengan model reka bentuk instruksi yang digunakan secara meluas. Dalam komponennya terbagi menjadi empat komponen yaitu attention (perhatian), relevance (relevansi), confidence (percaya diri), dan satisfaction (kepuasan). Model ini diharapkan mampu untuk membangkitkan motivasi belajar siswa sehingga dalam proses pembelajarannya keaktifan dan hasil belajar siswa dapat meningkat.

Hal ini diperkuat dengan hasil penelitian relevan yang dilakukan oleh Betanika Nila Nirbita (2016) yang mnenunjukkan bahwa dengan mengimplementasikan model ARCS pada proses pembelajaran dapat terjadi peningkatan aktifitas belajar Satisfaction) dapat meningkatkan keaktifan, motivasi, dan hasil belajar pada tahap pra tindakan sebesar 32,14\%, kemudian mengalami peningkatan sebesar 53,57 \% di siklus I dan meningkat sebesar 89,29 \% pada siklus II. Hal ini ditunjukkan partisipasi siswa dalam mengajukan pertanyaan/ide dalam diskusi meningkat 57,14 \%, partisipasi siswa dalam menjawab pertanyaan dalam diskusi meningkat 46,43\%, interaksi antar siswa dalam kelompok meningkat $50 \%$, ketekunan dan keuletan siswa meningkat 58,58 \%, siswa dapat menerima pelajaran yang disampaikan oleh guru dengan baik meningkat $28,58 \%$, siswa menjadi lebih senang belajar mandiri meningkat $60,71 \%$, siswa mengemukakan pendapat meningkat $57,14 \%$ dan hasil belajar siswa meningkat $71,43 \%$.

Keaktifan belajar diklasifikasikan menjadi 8 kelompok yaitu kegiatan visual, kegiatan lisan, kegiatan mendengarkan, kegiatan menulis, kegiatan menggambar, kegiatan metrik, kegiatan mental dan kegiatan emosional (Oemar Hamalik, 2011: 172-173). Dengan partisipasi aktif dalam proses pembelajaran, menunjukkan bahwa siwa sedang terlibat secara penuh dalam proses belajar sehingga dengan hal ini akan berpengaruh pada hasil belajar siswa. Hal ini sesuai dengan hasil penelitian yang dilakukan Herminarto Sofyan (2014) yang menunjukkan bahwa jika keaktifan siswa meningkat maka hasil belajar juga akan meningkat. 


\section{METODE}

Penelitian ini merupakan jenis Penelitian Tindakan Kelas (Classroom Action Research) dan termasuk dalam ruang lingkup penelitian terapan (Applied Research) yang menggabungkan antara pengetahuan, penelitian, dan tindakan.

Desain penelitian ini menggunakan model Kemmis dan Mc Taggart yang meliputi 4 tahapan dalam proses penelitiannya yaitu perencanaan (planning), tindakan (action), pengamatan (observation) dan refleksi (reflection)

Penelitian ini dilaksanakan di kelas X TKR A SMK Nasional Berbah, yang beralamat di Tanjungtirto, Kalitirto, Berbah, Sleman. Waktu yang digunakan peneliti melaksanakan penelitian pada semester 2 tahun ajaran 2019/2020 di kelas X TKR A dimulai bulan Januari sampai Februari 2019.

Data yang dikumpulkan melalui instrumen penelitian berupa teknik observasi aktivitas siswa dalam pembelajaran dengan aspek yang diamati meliputi :

(1) keberanian peserta didik bertanya, (2) keberanian peserta didik untukmenjawab pertanyaan/mengungkapkan pendapat, (3) interaksi peserta didik dengan guru, (4) perhatian peserta didik selama proses pembelajaran dan kelompok dan Tes evaluasi belajar sebanyak 20 soal dengan tipe soal yaitu pilihan ganda.

Instrumen yang digunakan dalam penelitian ini yaitu lembar observasi untuk mengetahui keaktifan siswa tiap individu dengan jenis numerical rating scale, dan lembar observasi keterlaksanaan model pembelajaran ARCS sesuai dengan sintak pembelajaran, serta tes evaluasi untuk mengetahui tingkat pemahaman dan hasil belajar siswa setelah diterapkannya pembelajaran dengan model ARCS. Jenis tes yang digunakan dalam penelitian ini adalah tes pilihan ganda untuk mengetahui hasil belajar siswa pada siklus I dan siklus II. Jenis validitas yang digunakan untuk instrumen ini adalah validitas konstruk yang dilakukan dengan expert judgement.

Teknik analisis data dalam penelitian ini meliputi : (1) analisis data keaktifan belajar siswa dengan numerical rating scale yaitu dengan berupa skor dari nilai terendah 1 dan nilai tertinggi 5 untuk setiap aspek penilaiannya.

Tabel.01 Interval Nilai Keaktifan Siswa

\begin{tabular}{|c|c|}
\hline Kategori & Nilai Keaktifan Siswa \\
\hline Tidak Aktif & $4-6$ \\
\hline Kurang Aktif & $7-9$ \\
\hline Aktif & $10-12$ \\
\hline Sangat Aktif & $13-16$ \\
\hline
\end{tabular}


Analisis data aktifitas siswa dikelas tiap siklus dapat ditentukan dengan :

Persentase $=\frac{\text { Skor aktivitas peserta didik }}{\text { Skor total aktivitas peserta didik }} \times 100 \%$

Keterangan :

Skor aktifitas siswa : Jumlah skor kegiatan yang dilakukan siswa dalam waktu pengamatan.

Skor total aktifitas siswa: Jumlah skor maksimal yang dilakukan oleh siswa. (2) Analisis data hasil tes belajar siswa : KKM untuk mata pelajaran Pekerjaan Dasar Teknik Otomotif di SMK Nasional Berbah adalah 75. Apabila siswa sudah mencapai nilai 75 dan diatas 75-100, maka dinyatakan siswa tesebut sudah tuntas. Sedangkan siswa yang mencapai nilai dibawah 75 maka dapat dinyatakan siswa tersebut belum mencapai nilai ketuntasan minimum. Berikut ini interpretasi hasil belajar siswa pada mata pelajaran Pekerjaan Dasar Teknik Otomotif.

Tabel. 02. Interval Nilai Ketuntasan Siswa

\begin{tabular}{|c|c|}
\hline Nilai & Keterangan \\
\hline$>75-100$ & Tuntas \\
\hline$<75$ & Belum Tuntas \\
\hline
\end{tabular}

Hasil pencapaian belajar siswa dapat dikatakan berhasil apabila siswa berada pada nilai rentang $>75-100$. Untuk menganalisa pencapaian hasil belajar siswa maka dapat menggunakan rumus sebagai berikut:

Presentase $=\frac{\text { Jumlah siswa yang tuntas }}{\text { Jumlah siswa }} \times 100$

Rata-rata hasil belajar siswa dapat diketahui dengan rumus berikut :

$$
M e=\frac{\sum X i}{N}
$$

Dimana :

$\mathrm{Me} \quad=$ Mean (rata-rata)

$\sum \quad=$ Epsilon (baca jumlah)

$\mathrm{Xi} \quad=$ Nilai $\mathrm{X}$ ke i sampai ke $\mathrm{n}$

$\mathrm{N} \quad=$ Jumlah individu

Indikator Keberhasilan Penelitian model pembelajaran ARCS dianggap berhasil apabila mampu meningkatkan keaktifan dan hasil belajar siswa pada saat posttest pada tiap siklus. Hasil belajar siswa bila nilai tuntas dapat dicapai $75 \%$ dari keseluruhan siwa dan keaktifan belajar siswa mencapai $65 \%$ dikelas X TKR A di SMK Nasional Berbah.

\section{HASIL DAN PEMBAHASAN}

\section{PEMBAHASAN}

Penelitian ini dilaksanakan selama dua siklus. Mata pelajaran yang digunakan selama penelitian adalah Pekerjaan Dasar Teknik Otomotif (PDTO) pada kompetensi dasar (KD) 3.5. 
80 Muhammad Solikhin

Menerapkan alat ukur mekanik beserta fungsinya. Dalam pelaksanaannya, setiap siklus penelitian ini menggunakan langkah-langkah penelitian tindakan kelas yaitu mulai dari perencanaan tindakan, pelaksanaan tindakan, observasi tindakan dan refleksi tindakan.

Pelaksanaan Model Pembelajaran ARCS yang digunakan dalam penelitian ini mempunyai 17 langkah pembelajaran. Pelaksanaan model pembelajaran ARCS ini dikatakan sesuai atau berhasil jika sesuai sintak dari model pembelajaran ARCS. Pelaksanaan model pembelajaran ARCS dari siklus I ke siklus II. Dari hasil penelitian mengenai pelaksanaan model pembelajaran ARCS pada siklus I dan II, dapat diketahui tingkat kesesuaian pelaksanaan metode ARCS dari siklus I ke siklus II mengalami peningkatan. Pada siklus I persentase kesesuaian pelaksanaan model pembelajaran tersebut sebesar $82 \%$ kemudian meningkat $18 \%$ pada siklus II menjadi $100 \%$. Berikut merupakan grafik yang menggambarkan peningkatan kesesuaian pelaksanaan model pembelajaran ARCS.

Grafik 01. Peningkatan Pelaksanaan Model Pembelajaran ARCS

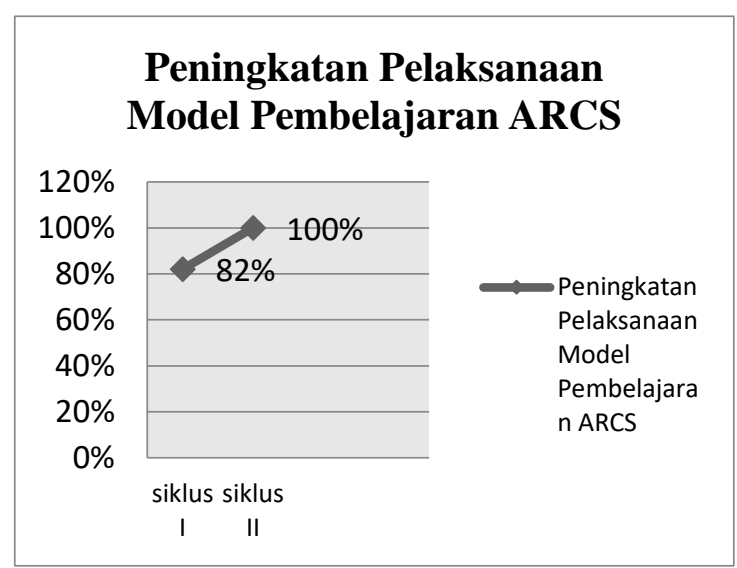

Keaktifan siswa dari siklus I ke siklus II. Dari hasil observasi dan analisis yang dicantumkan pada hasil penelitian maka diketahui bahwa persentase tingkat keaktifan siswa pada siklus I sebesar 55,60 \% atau dalam kategori belum mencapai indikator keberhasilan ang ditentukan dan pada siklus II ini persentase keaktifan siswa sebesar 73,71\% atau dalam kategori baik (mencapai indikator keberhasilan yang ditentukan). Dari hasil observasi tersebut maka dapat disimpulkan bahwa persentase keaktifan siswa dari siklus I ke siklus II mengalami peningkatan sebesar $18,11 \%$.

Berikut ini merupakan grafik berdasarkan dari hasil peningkatan keaktifan siswa yang terjadi dari siklus I ke siklus II. 
Grafik 02. Peningkatan keaktifan pelaksanaan model pembelajara ARCS

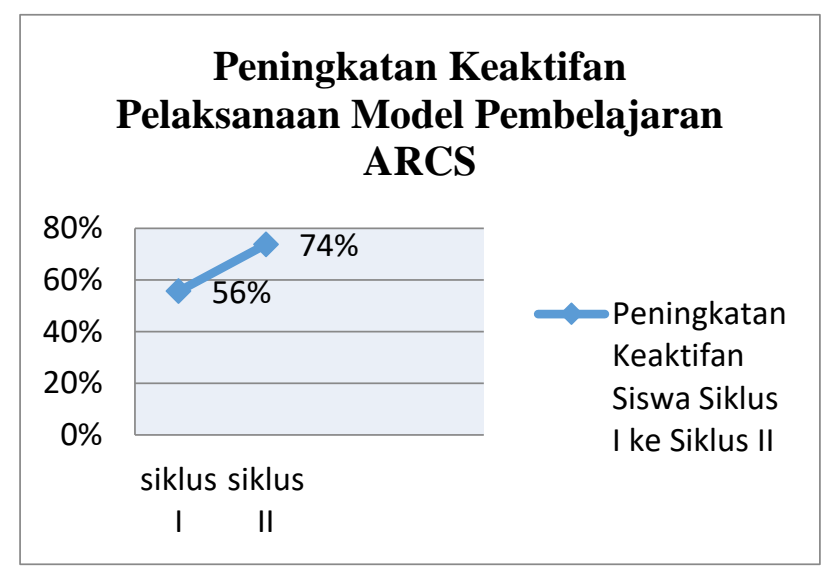

Persentase keaktifan siswa pada grafik tersebut, baik di siklus I maupun di siklus II didapat melalui banyaknya aspek indikator (4 aspek indikator) yang muncul karena dilakukan oleh siswa. Berikut merupakan diagram yang menunjukkan peningkatan jumlah munculnya masing-masing aspek indikator keaktifan dari siklus I ke siklus II.

Diagram 04. Frekuensi Kemunculan Indikator Keaktifan.

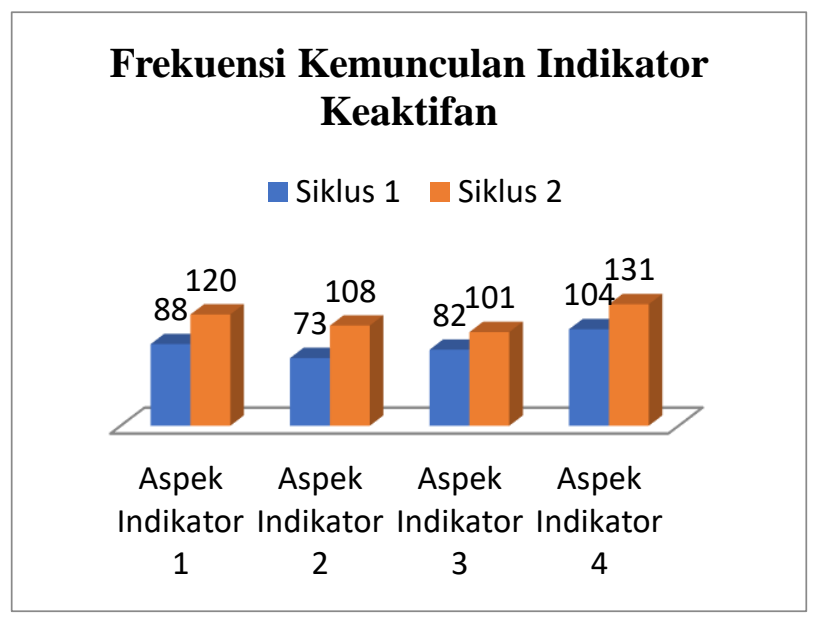

Tabel 03. Keterangan Tiap Aspek Indikator Keaktifan.

\begin{tabular}{|c|c|}
\hline Aspek & Keterangan \\
\hline $\begin{array}{c}\text { Aspek } \\
\text { Indikator } 1\end{array}$ & Keberanian siswa bertanya. \\
\hline $\begin{array}{c}\text { Aspek } \\
\text { Indikator } 2\end{array}$ & $\begin{array}{l}\text { Keberanian siswa untuk } \\
\text { menjawab } \\
\text { pertanyaan/mengungkapkan } \\
\text { pendapat. }\end{array}$ \\
\hline $\begin{array}{c}\text { Aspek } \\
\text { Indikator } 3\end{array}$ & $\begin{array}{l}\text { Interaksi siswa dengan guru } \\
\text { dan kelompok. }\end{array}$ \\
\hline $\begin{array}{c}\text { Aspek } \\
\text { Indikator } 4\end{array}$ & $\begin{array}{l}\text { Perhatian siswa selama proses } \\
\text { pembelajaran. }\end{array}$ \\
\hline
\end{tabular}


Hasil belajar dari siklus I ke siklus II. Dari siklus I ke siklus II, hasil belajar siswa dapat dikatatakan mengalami peningkatan. Hal ini dapat dilihat dari rata-rata hasil belajar siswa dan jumlah ketuntasan hasil belajar siswa. Pada siklus I jumlah siswa yang tuntas mencapai KKM sebanyak 15 orang dengan persentase ketuntasan sebesar 41,7 \% dan rata-rata nilai kelas 57,5. Pada siklus II, jumlah siswa tuntas mencapai KKM sebanyak 32 orang, dalam artian mengalami peningkatan, dengan persentase ketuntasan hasil belajar sebesar $82 \%$ dengan nilai rata-rata 75 . Peningkatan hasil belajar menurut Muhibbin Syah (2011:145) dipengaruhi oleh beberapa faktor diantaranya adalah sebagai berikut : (1) Faktor internal (faktor dari dalam siswa) yakni keadaan/kondisi jasmani dan rohani siswa (2) Faktor eksternal (faktor dari luar siswa) yakni kondisi lingkungan di sekitar siswa (3) Faktor pendekatan belajar (approach to learning) yakni jenis upaya belajar siswa yang meliputi strategi dan metode yang digunakan siswa untuk melakukan kegiatan pembelajaran materi-materi pelajaran.

Kondisi ideal di kelas X TKR A di SMK Nasional Berbah ketika proses pembelajaran yang terjadi di siklus II mengalami peningkatan pada kekondisifan kelas dengan penggunaan penggunaan model pembelajaran ARCS, dengan dipadukan dengan pembelajaran cooperative (berkelompok) mampu meningkatkan keaktifan siswa dalam proses kegiatan pembelajaran. Dengan peningkatan keaktifan pembelajaran maka berpengaruh pada hasil belajar siswa. Terjadinya peningkatan hasil belajar siswa ini tidak terlepas dari beberapa solusi perbaikan (hasil refleksi) dari siklus I, yang berhasil dilaksanakan pada siklus II. Berikut grafik yang menggambarkan peningkatan hasil belajar siswa dari siklus I ke siklus II.

Grafik 03. Peningkatan Hasil Belajar Siswa.

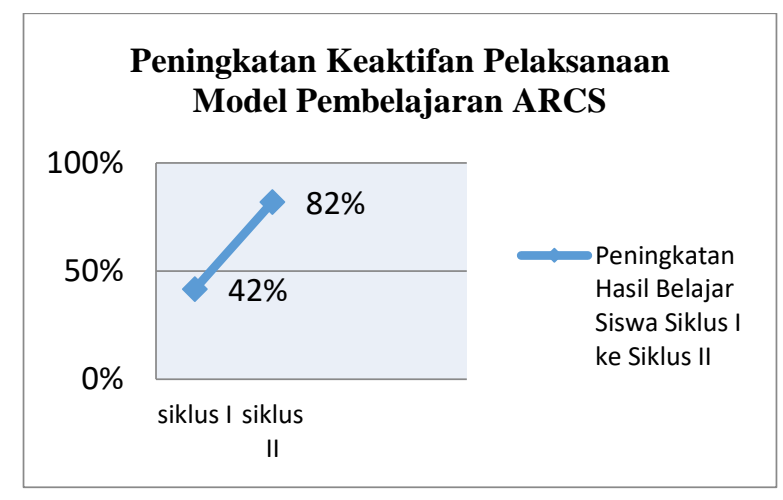

Keberhasilan Model Pembelajaran ARCS dalam meningkatkan Hasil Belajar Siswa. Berdasarkan dari hasil observasi awal yang digunakan sebagai permasalahan penelitian, diketahui bahwa nilai rata-rata hasil UAS siswa sebesar 51,48, dengan ketuntasan hasil belajar sebesar 35,90 \% (kategori belum mencapai indikator keberhasilan yang ditetapkan) atau hanya sebanyak 14 siswa yang mencapai KKM. Setelah diterapkannya model pembelajaran ARCS pada siklus I maka rata-rata hasil belajar siswa menjadi meningkat sebesar 57,5 dengan 
persentase KKM sebesar 41,7 \%. Kemudian di siklus II hasil belajar siswa mengalami peningkatan persentase KKM menjadi $82 \%$ (kategori sangat baik) dengan nilai rata-rata 75 .

Dari penjelasan tersebut dapat diketahui bahwa implementasi model pembelajaran ARCS dalam proses belajar dapat meningkatkan hasil belajar siswa di kelas X TKR A di SMK Nasional Berbah pada mata pelajaran Pekerjaan Dasar Teknik Otomotif (PDTO), sehingga berhasil mengatasi permasalahan penelitian yang berupa rendahnya hasil belajar siswa.

\section{SIMPULAN}

ARCS (Attention, Relevance Confidence, and Satisfaction) dapat meningkatkan keaktifan siswa kelas X TKR A pada mata pelajaran Pekerjaan Dasar Teknik Otomotif (PDTO) di SMK Nasional Berbah. Hal ini ditunjukkan dengan peningkatan persentase keaktifan siswa dari pra tindakan hingga siklus II. Pada siklus I keaktifan siswa sudah mengalami peningkatan dari tahap pra tindakan namun persentase keaktifan siswa pada siklus I sebesar 55,60 \% belum mencapai $\leq 65 \%$ dari indikator keberhasilan yang ditetapkan, sehingga dibutuhkan pelaksanaan siklus II. Pada siklus II persentase keaktifan siswa mengalami peningkatan, dengan persentase keaktifan sebesar $73,71 \%$ dari hasil presentase keaktifan siswa di siklus II telah mencapai indikator keberhasilan yang ditetapkan yaitu $\geq 65 \%$. Dalam hal ini menandakan bahwa penelitian ini telah berhasil meningkatkan keaktifan siswa.

Implementasi model pembelajaran ARCS (Attention, Relevance Confidence, and Satisfaction) dapat meningkatkan hasil belajar siswa kelas X TKR A pada mata pelajaran Pekerjaan Dasar Teknik Otomotif (PDTO) di SMK Nasional Berbah. Hal ini ditunjukkan dengan peningkatan persentase hasil belajar siswa dari pra tindakan hingga siklus II. Pada siklus I persentase ketuntasan hasil belajar siswa sebesar belum mencapai indikator keberhasilan yang ditetapkan $\leq 75 \%$, sehingga diperlukan siklus II. Persentase ketuntasan hasil belajar di siklus II sebesar $82 \%$ dalam hal ini mencapai indikator keberhasilan yang ditetapkan $\geq 75 \%$. Dalam hal ini menandakan bahwa penelitian ini telah berhasil meningkatkan hasil belajar siswa.

\section{DAFTAR PUSTAKA}

Hamalik, O. (2011). Kurikulum dan Pembelajaran. Jakarta: Bumi Aksara.

Sofyan, H., T. U. (22 Mei 2014). Peningkatan Mutu Pembelajaran Teknologi Pengecatan Melalui Metode Jigsaw Bagi Mahasiswa Otomotif FT UNY. Jurnal JPTK Vol 22.

Sofyan, H. (2015). Metodologi Pembelajaran Kejuruan. UNY Press, Yogyakarta.

Sofyan, H., Suyanto, W., Budiman, A., Siswanto, I., Gumelar, A., \& Ruswanto, W. A. (2019). PELATIHAN PENELITIAN TINDAKAN KELAS DENGAN VARIASI METODE DAN MEDIA PEMBELAJARAN UNTUK MENINGKATKAN KEMAMPUAN PENULISAN KARYA ILMIAH GURU-GURU SMK NEGERI 3 YOGYAKARTA. Jurnal Pendidikan Vokasi Otomotif, 2(1), 11-22. 
84 Muhammad Solikhin

Sukmadinata, N. S. (2012). Kurikulum dan Pembelajaran Kompetensi. Bandung: PT. Refika Aditama.

Syah, M. (2013). Psikologi Pendidikan dengan Pendekatan Baru. Bandung: PT. Remaja Rosdakarya. 